\title{
History and Grammaticalisation of "Doch"/"Toch"
}

\author{
Henk Zeevat
}

ILLC, University of Amsterdam

Elena Karagjosova

University of Stuttgart

The paper investigates the origins of the German/Dutch particle toch/doch) in the hope of shedding light on a puzzle with respect to doch/toch and to shed some light on two theoretical issues. The puzzle is the nearly opposite meaning of the stressed and unstressed versions of the particle which cannot be accounted for in standard theories of the meaning of stress. One theoretical issue concerns the meaning of stress: whether it is possible to reduce the semantic contribution of a stressed item to the meaning of the item and the meaning of stress. The second issue is whether the complex use of a particle like doch/toch can be seen as an instance of spread or whether it has to be seen as having a core meaning which is differentiated by pragmatics operating in different contexts.

We use the etymology of doch and doch as to+u+h (that+ question marker+ emphatic marker) to argue for an origin as a question tag checking a hearer opinion. Stress on the tag indicates an opposite opinion (of the common ground or the speaker) and this sets apart two groups of uses spreading in different directions. This solves the puzzle, indicates that the assumption of spread is useful and offers a subtle correction of the interpretation of stress. While stress always means contrast with a contrasting item, if the particle use is due to spread, it is not guaranteed that the unstressed particle has a corresponding use (or inversely).

\section{Introduction}

Dutch toch or German doch give rise to an almost paradoxical question, first noted by Doherty(1985). If the sentence is presented with stress on toch/doch the conditions of use become the opposite from the same sentences with the stress removed.
(1) Hij komt тосн.
Er kommt DOCH. 
He is coming, although we believed he was not.

(2) Hij komt toch.

Er kommt doch.

You know he's coming.

The first speech act (1) is a correction, normally of the common ground between speaker and hearer and the second speech act (2) is a reminder of some common ground fact. The problem is how to derive these two different uses from the same conceptual source (the meaning of doch/toch) and a general account of the import of accent in interpretation. It is not an easy problem, since in Rooth's account of accent (Rooth 1992) all that accent contributes is the salience of an alternative to the accented part, here the particle. That works fine in (1), since the interlocutors believed (3), a clear alternative in the sense of Rooth. It can therefore be explained why accent appears on the particle in (1) but the explanation fails completely to predict why a quite distinct speech act results when the accent is omitted. One should be back at the core meaning without a salient alternative. But what is a correction of the common ground without a salient element of the common ground to be corrected? And what would it mean to remind somebody of a known fact while making its negation salient?

(3) Hij komt NIET.

Er kommt NICHT.

He is NOT coming.

Notice that in (2) other alternatives can be salient.

(4) PETER war doch in Frankfurt.

You know it was Peter who was in Frankfurt.

(4) will have a salient alternative, say You know it was John who was in Frankfurt, so the problem is not that reminders cannot have salient alternatives. The problem is that (3) is the only good alternative to (2) and assuming it is salient seems to destroy the point of the reminder and moreover does not lead to the meaning of (1). It would appear that the particle with accent and the particle without accent have acquired independent meanings and that -contrary to what is generally assumed- Dutch and German are distinguishing words by means of word intonation alone.

In this paper, we explore the history of the particle in order to solve this problem, largely in order to see whether progress can be made by applying the ideas in Zeevat (2007) about spread in language evolution. Our claim is that in 
its original meaning the intonational contrast is as expected. Spread of uses of both the accented and unaccented toch/doch has resulted in a set of new uses, related to but distinct from the original use. Certain of those uses cause accent to appear because there is a contrasting and activated alternative, while other uses rule out accent. This results in accent (with the syntactic position of the particle) being one of the factors that disambiguates between the different uses of doch/toch. Accent in this view does not have its own meaning, but it has a triggering condition. The triggering condition is compatible with only some of the possible uses. There could be no compositional theory that takes the meaning of doch and the meaning of accent and combines them into the meaning of accented doch.

In section (2), an overview is presented of the different German and Dutch uses. Section (3) is about the view that words like toch/doch can be described by means of a core meaning. Section (4) discusses the alternative model of spread in the evolution of languages. Section (5) provides apossible historical explanation.

\section{Overview of the uses of doch and toch}

This section is an overview of the uses of doch and toch in German and Dutch. While there is a large overlap, there are also differences. Labels are introduced for the uses and these labels are used later on in the text. The overview is close to Foolen (2003), but adds some differences between Dutch and German.

\section{Questions with assertion syntax}

Asking for confirmation of something the other speaker said, prompted by having the opposite information (correction confirmation question):

(5) Hij komt DOCH?

Er kommt DOCH?

Is he coming after all?

Confirmation of old common ground information, to make sure, or because the other seems to have forgotten (reminder question):

(6) Hij komt toch?

Er kommt doch?

You know he's coming, isn't he?

(7) Ik ga toch 2 weken weg? 
Ich bin doch weg die naechste zwei Wochen?

You know I am away the next two weeks?

It is one of the most remarkable properties of doch/toch that it can make assertive sentences into questions. Unaccented doch/toch cannot be used with inversion, at least in polar questions.

\section{Questions with question syntax}

Asking for confirmation of correction of common ground: you were not coming but now you seem to be. They are not different from the corresponding question without inversion:

(8) Kom je тосн ?

Kommst du (also) DOch?

So you are coming after all?

Inversion is not possible with unaccented toch/doch:

(9) *Kom je toch?

*Kommst du (also) doch?

\section{Assertions}

Correction of common ground:

(10) Hij komt тосн.

Er kommt DOCH.

He is coming after all.

\section{Correction particle}

TOCH WEL and DOCH: correction of negation:

(11) TOCh WEL/NIET)!

DOCH (NICHT)!

No!

\section{Proconcessive use:}

The previous context contains a reason for thinking otherwise, which must be 
identified in a proper interpretation. The accent is weaker than in the correction cases.

(12) En TOCH kwam hij.

Und Doch kam er.

He came though.

Reiteration of old common ground information:

(13) Hij komt toch.

Er kommt doch.

He's coming, you know he is.

\section{Common ground marker:}

(14) Als je toch hierheen komt, neem het boek dan mee.

Falls du sowieso hierher kommst, nimm das Buch dann mit. (not with doch).

If you are coming here anyway, bring along the book.

\section{Reminding causal:}

(15) Ik ben immers rijk. (not with toch)

Bin ich doch reich. (with obligatory inversion)

Because, as you know, I am rich.

\section{Imperatives}

Idiomatic: refusal to believe the other is sincere in what he is saying:

(16) Kom toch!

Not in German.

Come on.

Non-idiomatic: exhortation to come, mitigating the imperative by presuming a common ground that this is the correct thing to do (?):

(17) Kom toch!

Komm doch!

Do come! 
Request for coming, while it was clear the interlocutor would not do that.

(18) Kom тосн!

Komm DOCH!

Change your mind and come!

\section{Wh-questions}

Reasking an already answered direct question when one has forgotten the answer:

(19) Wie heeft er toch dat artikel over contrast geschreven?

Wer hat doch dieses Papier über Kontrast geschrieben?

Who was it that wrote this paper about contrast?

(20) Wat was dat toch voor voetbalwedstrijd?

Was war das doch für ein Fußballspiel?

What soccer game was that?

(21) Wie heeft er toch de cake opgegeten?

Wer hat denn den Kuchen aufgegessen? (not with doch)

Who ate the cake?

The meaning of doch/toch is not clear in the last two cases. They are only available with the unaccented doch and toch. It seems the wh-question must related to a common ground fact.

\section{Exclamations}

Exclamation of criticism of addressee:

(22) Peter toch!

Aber Peter! (not with doch)

But Peter!

Exclamatives (surprise over CG fact?):

(23) Wat is hij toch slim!

Wie klug er doch ist!

How clever he is! 
Wishes (their fulfillment is already in the CG?):

(24) Als hij toch zou komen! Wenn er doch käme! If he would come!

\section{Conjunction}

Adversative conjunction:

(24) Die Lage ist ernst, doch nicht hoffnungslos. Not in modern Dutch.

The situation is serious but not hopeless.

\section{The same root in other languages}

\section{English}

Proconcessive:

(25) He is coming though.

Doch kommt er.

Toch komt hij.

\section{Concessive conjunction:}

(26) Though he is ill, he is still coming.

Not with toch or doch.

\section{Swedish}

dokh, apparently taken from German. Mostly proconcessive.

\section{Spoken Russian}

The reminder clitic particle -to (McCoy 2003).

\section{Gothic}

Will be discussed in section (5). 


\section{Sanskrit}

tu as the contrastive conjunction Sturtevant (1928). According to Jared Klein (p.c.) this is no longer the accepted theory about the origin of $t u$. Without Sanskrit and ignoring the Russian reminder particle, there is no evidence for a pre-Germanic origin of doch/toch.

\section{Core meanings}

As stated in the introduction, the main two assertion uses are distinguished by intonation. Without accent toch/doch is a modal particle for common ground status and with accent, it becomes a correction particle. These are near opposites and it seems hard to connect the two uses from a core meaning and intonation.

(27) Peter kommt DOCH.

Peter is coming and we thought he was not.

(28) Peter kommt doch.

Peter is coming as we always thought.

How to do this with intonation theories? Following Rooth (1992), the accent relates to a set of alternatives that can be obtained by replacing elements of the same category for the accented item. For Rooth, it only depends on the context which substitution instances are in the set. Zeevat (2004) argued that proper alternatives to $x$ must be distinct from $x$ and that distinctness requires that it is incompatible with the common ground that the two items could still be identical or overlapping. For the category of particles to which TOCH/DOCH belongs this would work out as conceptual incompatibility. That condition is only fulfilled by full negation, so that Peter kommt NICHT is the only alternative.

In the correction use, the correct alternative is given by the common ground knowledge that is to be corrected. It is of the form $p$ if the utterance is DOCH NICHT $p$ and of the form NICHT $p$ if the utterance is DOCH $p$. But taking the meaning of the unaccented doch ( $p$ is common ground) and adding to that the salience of the negation of $p$ does not give us a correction. $p$ is precisely not common ground if the correction $p$ makes any sense and it is not possible to assume that not-p is common ground if $p$ is also common ground. Correction with unaccented doch is possible when the other speaker seems to have withdrawn his earlier commitment to $p$. Doch is used in this case to remind the other speaker that $p$ really is common ground.

One strategy that one can follow to solve this puzzle is to assume a core meaning for toch/doch that underlies both the accented and the unaccented 
toch/doch which derive their meaning in a given context from the core meaning and pragmatically based reasoning about the content in the context.

One of the most worked-out approaches on this line is Karagjosova (2003) that proposes a core meaning of denial of earlier expectation, following earlier work of Weydt (1969). In the case of correction, the earlier expectation can be equated with whatever is corrected.

(28) Peter ist also Doch verreist.

Although I had reasons to believe that Peter would not leave, he has left.

In the non-accented case it is denial of the speaker's expectation about what the hearer believes. In the example below, B expects A to believe that Peter is away on a journey, but A's contribution can only be taken as indicating that $\mathrm{A}$ has forgotten all about it.

(29) A. Peter kommt also mit.

B. Er is doch verreist.

A. Peter is coming along then.

B. But he has left, hasn't he?

In the case of the accented DOCH, one can take the salient negative alternative presupposed by the accent on DOCH as a way of indicating which expectation is violated: the expectation that Peter would not have left on a journey. And in fact one can show that there is a whole range of possible sources for the violated expectation with the common ground only being one of them: the speaker only, the hearer only, third party opinions, the linguistic context, a plausible inference from what has just been said. For the unaccented doch, the speaker's expectation that the hearer believes $p$ is a plausible basis for assuming that $p$ is common ground between the speaker and the hearer. If the speaker expects the hearer to believe $p$ but does not in fact believe $p$ herself, presumably she should indicate her dissent.

What are the problems with this account? First of all, while denial of expectation is a common ingredient of both denial of an expectationabout the hearer's belief that $p$ and denial of expectation that $p$, it is not clear that an intonational account on the lines of Rooth (1992) is able to relate the two expectations. Why should accent lead to denial of expectation with respect to $p$, when it is just the denial of the expectation that the hearer believes $p$ in the unaccented case? This would not be a straightforward application of what is understood about accent. 
The second problem is that there are subtle differences between Dutch and German: combining unaccented doch with questions is more frequently out, and there are cases like (29) that are not in German.

(29) Als je toch hierheen komt, neem het boek dan mee.

If you are coming here anyway, bring along the book.

Falls du sowieso hierher kommst, nimm das Buch mit.

Now if the core meaning is the same in both languages (and there is a very large overlap) the same pragmatical reasoning should apply and there should be no such distinctions. In addition, the proposed core meaning seems to be absent in (29): it is common ground between speaker and hearer that the hearer will come to the location of the speaker and that common ground knowledge is just mobilised for planning the return of the book: there is no suggestion at all that the hearer has forgotten about his plan to come over. A similar case is the following example.

(30) Ik ga toch 2 weken weg?

Ich bin doch weg für 2 Wochen?

As you know I am away for two weeks?

There is no indication in this example that the hearer does not know anymore about the speaker's travelling plans: the purpose of the speaker is just to bring it up again so that she can now ask the hearer to water her plants while she is away. (The absence in Dutch of the particle ja may explain why Dutch has a wider range of uses here: $j a$ is a less ambiguous common ground marker). The reminding causal uses in German (Bin ich doch reich.) are however another case in point.

So while we accept in principle the possibility of a core meaning approach, we have doubts in this particular case with respect to the possibility of a core meaning theory that meets the two demands: (a) the core meaning is present in all uses and (b) each use can be fully explained using the core meaning and pragmatic reasoning only. There seems to be no proposal that fully does the job.

It is a point in favour of core meaning theories that they do justice to the intuition of a conceptual unity behind a rich variety of uses. But it does not seem that the alternative theory of a historical process in which the different uses are formed is unable to account for this intuition. A historical account has the advantage that differences between languages are not problematical and that the pragmatical reasoning becomes superfluous, or gets a different role. This is the road that we will pursue in the next section and beyond. 


\section{$4 \quad$ Spread in Grammaticalisation}

Zeevat (2007) investigates the possibilities of simulating one central step in the grammaticalisation process in a probabilistic model: the recruitment of a word for a new use. In recruitment, an existing word acquires a new use, often described as weaker, more pragmatical and grammatical. Recruitment is the standard process assumed for the origin of the functional inventory of languages: all grammatical morphemes, auxiliaries, articles, prepositions, pronouns and particles, with the possible exception of demonstratives ultimately derive from lexical words by recruitment.

The model makes reproduction of a use dependent on its communicative success, i.e. on whether the hearer correctly identifies the speaker's intention and of the importance of the error (important errors lead to less reproduction). On this basis, historical events like spread and usurpation can be simulated by the change of probabilities guiding the use and interpretation of linguistic expressions for certain meanings. This makes recruitment happen only when three conditions are satisfied:

a. the source use weakly entails the target use (if the source use obtains, the target use holds more often than not) (push)

b. non-recognition of the target use leads to "serious" communicative failure

c. non-expression of the target meaning is overwhelmingly interpreted as excluding the target use (with $\mathrm{b}$ together: pull) and the target meaning lacks an alternative expression device.

Without push, the use of the word is not able to evoke the new meaning, without pull there is no reason for the new formation.

Depending on the relative natural frequencies of the old use versus the new use, the new use can either end up coexisting with the old use (spread) or take over the word entirely (usurpation).

Usurpation is also prevented if the new use and the old use are protected from each other, i.e. there are features of both uses such that confusion of an old use for a new use or vice versa is unlikely. The attested grammaticalisation of words for "head" to become the local preposition corresponding to English on is a case in point, since the prepositional and noun uses cannot be confused for each other in this case.

As an example consider spread as an account for the proconcessive use of toch/doch as derived from its correction use:

a. the fact that the common ground contains an opposite opinion of the speaker, the hearer or somebody else weakly entails that the common ground contains 
recent information from which one may infer the opposite of what is said -People's opinions are reasons for thinking that what they say is true

b. non-recognition leads to the availability of $p$ in memory as a reason for thinking that not- $q$--- while $q$ is the case.

(31) It rains. Peter is going for a walk.

(If it rains, people normally do not go for walks.)

Marking Peter's walking by a proconcessive is effective in removing the inference that Peter is not going for a walk.

c. A plain assertion is an answer to a fully open issue.

Compare Stalnaker's assertion conditions (Stalnaker 1979) that $p$ is both new and consistent information, but the assumption used here is stronger: the common ground should not already contain reasons for inferring that $p$ is true or false.

Further notice that in conversation the proconcessive use does not seem morefrequent than correction and that it is hard to confuse one for the other: if there is no CG element that is corrected by the statement, the correction interpretation is out. If there is nothing in the context that normally causes the statement to be false, the proconcessive interpretation is impossible.

So spread of a correction marker to become both a correction and a proconcessive marker is possible and will happen in due time in the model unless there are other candidates for recruitment or other good ways of expressing the new meaning. It follows that it must be assumed that the other German proconcessives, e.g. trotzdem must have evolved as proconcessives after doch became one.

It is not necessary to think of spread as creating two different words just because there are two different meanings. In a study of the use of already as a perfective aspectual marker in Singapore English (next to its standard English use), Fong (2003) proposes the mechanism of semantic epenthesis. In this mechanism, the word projects a set of semantic features and the context can switch some of them off. Applied to this case, one could think of the correction marker spread to proconcession as projecting the combination of proconcessive $(X)$ and correction $(X)$, with $X$ standing for the antecedent, so that the existence of a proconcessive antecedent switches of the correction reading or vice versa. (Notice that it is impossible to be both the negation of $p$ and a reason for $p$ being false, i.e. to be both the corrected item and the proconcessive 
antecedent). Along these lines, a conceptual unity of the word can be maintained, even after spread.

What can spread do for toch/doch? Can one relate the different uses by postulating recruitment or other processes?

It is important below that the arrows are monodirectional: it should not be possible for the inverted process to happen.

It seems the uses in section (2) can be derived from each other partly by spread in the following way. This was already demonstrated for (b.) and it is plausible for (e.) as well.

a. correction confirmation question $=>$ correction marking on anything

b. correction marking $=>$ proconcessive

c. proconcessive $=>$ contrastive conjunction

d. reminder question $=>$ CG marker

e. CG marker => mitigator (Abtönungspartikel) of imperatives, wishes, questions, exclamations, etc.

f. correction marker $=>$ correction particles

(DOCH (TOCH and TOCH WEL), and DOCH NICHT (TOCH NIET))

(c.) is a different case. The proconcessive doch occurs clause-initially and the process underlying the formation would be a reanalysis of the antecedent and the doch-clause as a single sentence and of doch as a conjunction. (a.) and (d.) can be analysed as spread by assuming that intonation separates their use as a marker of correcting questions or reminding questions from their use as correcting or reminding assertions. The assertive force is then intonationally expressed (which epenthesises the question feature) and leaves the correcting or reminding feature. This would be a case of semantic epenthesis: the correcting confirmation question marker used on an assertion cannot mark "confirmation question" but still projects "correction". Similarly, a reminder question marker on an assertion, cannot mark "question" but "reminder" can still be projected.

This spread would result in accented toch/doch becoming a marker of correction and unaccented toch/doch in a marker of common ground.

A marker of common ground (e.) can likewise easily spread into being a mitigator. Asking somebody to do what they want to to do anyway preserves face. Once mitigation has been established, it can further spread to wishes and questions.

Finally (f.) would come out of a process of ellipsis.

It is hard to see however that there is spread that connects the accented with the unaccented dochs. There are just two families of uses. A curious exception is the conjunction doch that is unaccented and so seems to fall outside the family 
of accented dochs to which it semantically belongs. It must be a property of conjunctions that they lose accent.

There are versions of toch/doch in other languages. English has though as a concessive conjunction and as a proconcessive, Swedish has dokh (adversative and concessive meaning), Russian -to (a reminder postclitic). These seem to be only fragments of the Dutch and German use and are not divided by accent. Gothic has a very wide range of otherwise unattested uses of thau, in addition to uses like the Dutch and German use.

The conclusion should be that while spread helps in accounting for the many uses (and liberates us from the task of accounting for the different uses by pragmatic reasoning from a core meaning), it still is unable to deal with the paradox with which this paper opened.

\section{A Historical Explanation}

In this section, we give a historical explanation of the paradox.

The particles doch and toch are derived from an Indogermanic origin to $+u+h$ composed of the demonstrative to, the question marker $-u$ and an emphatic marker $h$ Hentschel (1986). Given the nature of Indogermanic question marker in which the marker $-u$ can be attached to anything that is questioned, a gloss may be That? or Is that so?.

It should have a role in the sentence and the most reasonable role would seem that of a question tag on an assertion: $\mathrm{S}$, is that so?

There are three kinds of confirmation question. One can try to confirm one's own opinion, the opinion of a third party and one can confirm the opinions of the interlocutor. For the first kind, there are the so-called biased questions:

(32) He is guilty, isn't he?

He is guilty, yes?

He is guilty, right

For confirming the opinion of a third party, an open question that quotes the opinion seems the most appropriate.

(33) Is it true/correct that he is guilty?

The hearer's opinion is checked with rising intonation questions.

(34) He is guilty?

He isn't guilty?

Is he guilty? 
Isn't he guilty?

The Dutch and German questions in (34) have one property in addition to such rising intonation questions. They also presuppose the negation to be common ground. The surprise and the bias in (34) can also be due to the speaker's private opinion. (34) and (35) however both seek confirmation of what the hearer just said.

(35) Hij is TOCH schuldig?

Er ist DOCH schuldig?

Is he guilty after all?

How about the unaccented versions?

(36) Hij is toch schuldig?

Hij is toch niet schuldig?

Er ist doch schuldig?

Er ist doch nicht schuldig?

Here an old hearer/CG opinion is checked, quite possibly in reaction to some opinion of the hearer that casts doubt upon it. If so, it follows that the English question with reversed polarity is the adequate translation. But those can also be used if the speaker does not take his opinion to be common ground.

(37) Hij is toch schuldig?

Isn't he guilty?

Hij is toch niet schuldig?

Is he guilty?

This relation with a claim of the hearer disappears when the reminder question has other reasons than seeking for confirmation as in (38)

(38) Ik ga toch volgende week naar Spanje? Kan jij dan voor de planten zorgen? Ich bin doch nächste Woche in Spanien? Kannst du für meine Pflanzen sorgen?

When I am in Spain next week, can you water my plants?

In both cases to $+u+h$ would get tagged onto a hearer opinion and thereby the hearer would be asked to confirm it. In both cases the hearer has committed herself to $p$ in the past. The speaker wants to confirm whether the commitment is valid or still valid. 
In Dutch and German these uses are still there and they are the only two uses where the same pragmatic meaning (please confirm that you believe $p$ ) is invoked with accent (indicating an activated contrasting not- $p$ and without.

In section (4) it was shown how spread can account for the other Dutch and German uses.

There has been little development in the development of doch and toch in the recent history of German or Dutch. In fact, the very sim larity between the Dutch and the German particle indicates that nearly all of the uses were in place when the languages separated and that the formation of the particle is very old. If moreover the Russian -to really has the origin postulated, toch etc. predates the split between Germanic and Slavic.

The arguments that can be given for the original meaning are the etymology and especially the presence of the question marker $-u$ in it. The to picks up the preceding sentence and the $-u$ questions it. That the sentence should be a repetition of something the hearer has said or confirmed before does not follow in the same way. But it is clear that is that so? on its own would be just a challenge to the hearer.

Further, among the uses in German and Dutch, it appears to be the only two that can both serve as a source for al the other uses by spread and the only two that can be semantically related to each other by having or lacking contrastive stress.

It should further be noted that with the exception of Gothic none of the other languages have uses of their descendant of $t o+u+h$ that are not part of the Dutch/German array of uses and Gothic has a large overlap.

A weak spot is that there is no older German, older Dutch or Gothic evidence for these two original uses. This may be due to the fact that no real conversations are available for those languages and language phases. Confirmation questions typically slow down a story and the typical uncertainty about hearing it right in conversation is not part of the writing medium.

The argument requires the explanation of the Gothic uses that are not in Dutch or German.

The Gothic uses of thau can be resumed from the dictionary Streitberg (1910):

a. comparative conjunction: than after comparative

b. in disjunctive questions (also elliptic ones): or

c. adversative conjunction: jedoch

d. introducing the consequent of a conditional sentence: translation of Greek an

e. pragmatic ("metacommunicative") function: in proper direct and indirect (wh)-questions, rhetorical (wh-)questions and assertions

f. though as in English 
Uses (c.) and (f.) are familiar from German, English and Dutch.

Comparative conjunction may be related to a different use of to as in the English (39).

(39) Is he that strong?

In the equivalent of John is stronger than Bill, the combination of to with $-u$ would then be asking the hearer to answer the question how strong Bill is and uses that answer to make a statement about how strong John is. (Degrees to which $x$ has the property $P$ are often used in semantics for comparatives).

The marker of disjunctive questions can be related to examples like:

(40) skuld-u ist unsis kaisara gild giban thau ni-u?

is it right to give the emperor taxes or not?

It would seem that thau niu is a question tag like the Chinese $X$ bu $X$ as in (41) and that thau has been reanalyzed as a disjunctive question marker in this tag.

(41) Ni hao bu hao?

You good not good?

Are you doing well?

The uses in (d.) and (e.) are markers of non-veridicality and the recruitment of a question tag for this purpose seems natural. The somewhat mysterious modern uses of toch in dutch questions may perhaps be related to these Gothic uses. For our point, it is important that there is still a strong association with the marking of questions and non-veridicality. This makes an origin of toch and doch as question tags more plausible.

If we are right, this solves the paradox. The original use is not paradoxical, but both uses have spread a good deal. The accented toch/doch has become a correction and a concession marker and lost its association with questions. The unaccented toch/doch has become a marker for common ground information, again without an inherent relation with questions. But the new uses in the two groups cannot be related with uses in the other group as their contrastive or noncontrastive counterpart.

This merely points to the fact that accent is always assigned to a word in a particular use. Contrastive accent merely means that a contrasting element has been activated, as Rooth (1992 has it. Accent therefore plays a disambiguating role, but it does not do that as part of the inventory of sound distinctions that keep words apart in Dutch an German. It is merely a question of expressing the 
presence of a contrastor, which accidentally helps to keep various uses of toch and doch apart.

Apart from contrastive accent, uses are also kept apart by the rising intonation typical of questions and by sentential position and inversion.

The solution to the paradox starts from a shared origin of the accented and the unaccented doch. We postulate that this is as a marker of questions with which the speaker seeks a reconfirmation of a hearer opinion. The accented doch indicates that, in the context, the opposite opinion is also around, often as an element of the common ground that speaker and hearer share. The absence of accent indicates that the opposite opinion is not activated. Spread created a considerable ambiguity and accent (together with syntactic factors and rising and falling intonation) helps to keep the different uses apart.

\section{References}

Doherty, M. (1985). Epistemische Bedeutung. Akademie-Verlag, Berlin.

Fong, V. (2003). Unmarked 'already': Aspectual expressions in two varieties of english.

Foolen, A. (2003). Niederlaendisch toch und deutsch doch: Gleich oder doch nicht ganz? Linguistics Online, 13(1/3).

Hentschel, E. (1986). Funktion und Geschichte deutscher Partikeln. Ja, doch, halt und eben. Tuebingen.

Karagjosova, E. (2003). The Meaning and Function of German Modal Particles. Ph.D. thesis, University of Saarbruecken.

McCoy, S. (2003). Connecting information structure and discourse structure through Kontrast: The case of colloquial Russian particles -to, ze, and ved'. Journal of Logic, Language and Information, 12(3), 319-335.

Rooth, M. (1992). A theory of focus interpretation. Natural Language Semantics, 1, 75-116.

Stalnaker, R. (1979). Assertion. In P. Cole, editor, Syntax and Semantics, volume 9. Academic Press, London.

Streitberg, W. (1910). Die Gotische Bibel. Zweiter Teil: Gotisch-griechisch-deutsches Worterbuch. Carl Winter's Universitaetsbuchhandlung, Heidelberg.

Sturtevant, A. M. (1928). A note on the Gothic particle thau. Modern Language Notes, 43(4), 242-244.

Weydt, H. (1969). Abtonungspartikel . Bad Homburg.

Zeevat, H. (2004). Contrastors. Journal of Semantics, 21, 95-112.

Zeevat, H. (2007). Simulating recruitment in evolution. In G. Bouma, I. Kramer, and J. Zwarts, editors, Cognitive Foundations of Interpretation, pages 175-194. KNAW, Amsterdam. 